This study, like those reported from other transplant units, did not rely on historical controls but was a retrospective analysis of concurrently treated groups. Haybittle ${ }^{4}$ states that when there is a large difference between two groups in such an analysis the following criteria must be satisfied before acting on the result: the results should be supported by other, similar studies (our study is supported by those referenced and by others); there should be a logical explanation (the phenomenon of immunological enhancement provides this in our case); and there should be experimental backing. ${ }^{5}$

At least one multicentre trial is being established to determine whether preoperative blood transfusion improves graft survival. With such a large difference between the groups, is this multicentre trial necessary or even ethical ? Should units be prepared instead to accept retrospective studies after detailed analysis of the results of the individual units and clinicians has been carried out, and then proceed by giving preoperative transfusions to all patients to see if their results are improved ? Such a study could be historically controlled if no other changes in transplant policy are planned. Peto et $a l^{6}{ }^{6}$ while arguing against historical controls, stated, "if the new treatment cures almost everyone who would previously have died, historical controls may suffice to demonstrate this adequately."

The purpose of this paper is not to make overstrong claims based on a small series of cases but to stimulate other British transplant units to analyse and publish their data on similar lines. The Newcastle unit did so recently, with similar results. ${ }^{7}$ If the great majority of British units found the same trend, with no other factor responsible, then action without a preliminary trial would seem to be the reasonable course. Raising the overall success rate of first cadaver transplants to $75 \%$ by reducing the number of kidneys lost from early acute rejection would overcome many problems.

We thank Dr J Haybittle, department of physics, Addenbrooke's Hospital, Cambridge, for the statistical analysis of our data.

\section{References}

1 National Organ Matching Service, Annual Report (1975-76). Bristol, 1977.

2 Opelz, G, and Terasaki, P I, Lancet, 1974, 2, 696.

3 Knapp, M S, Lancet, 1977, 2, 696.

4 Haybittle, J, personal communication.

${ }^{5}$ Fabre, J W, and Morris, P J, Transplantation, 1972, 13, 608.

${ }^{6}$ Peto, R, et al, British fournal of Cancer, 1976, 34, 585.

7 Uldall, P R, et al, Lancet, 1977, 2, 316.

\title{
Comparison of serum oestrogen concentrations in post-menopausal women taking oestrone sulphate and oestradiol
}

\author{
ANNE B M ANDERSON, E SKLOVSKY, LINDA SAYERS, PENELOPE A STEELE, A C TURNBULL
}

British Medical fournal, 1978, 1, 140-142

\section{Summary and conclusions}

Mean serum concentrations of oestradiol-17 $\beta$, oestrone, and oestrone sulphate in postmenopausal women were the same when measured up to six hours after treatment with either piperazine oestrone sulphate $1.5 \mathrm{mg}$ or oestradiol valerate $2 \mathrm{mg}$. Maximum concentrations of oestradiol were less than those of oestrone, but oestrone sulphate reached concentrations about 30 times higher than those of oestrone.

The rapid conversion of oestradiol valerate to oestrone and oestrone sulphate does not support the suggestion that in menopausal women oestradiol is less likely to be associated with a risk of endometrial carcinoma than oestrone sulphate, since the two preparations appear to become identical after ingestion.

Nuffield Department of Obstetrics and Gynaecology, John Radcliffe Hospital, Headington, Oxford OX3 9DU

ANNE B M ANDERSON, MD, PHD, honorary consultant in clinical reproductive physiology

E SKLOVSKY, medical research assistant

LINDA SAYERS, BSC, research assistant

PENELOPE A STEELE, MSC, medical student

A C TURNBULL, MD, FRCOG, professor

\section{Introduction}

In 1975, reports from the United States ${ }^{12}$ suggested that oestrogen treatment at the time of the menopause might be associated with endometrial carcinoma. Several objections to this were raised, ${ }^{3-5}$ although some reports supported the association. ${ }^{6} 7$ The oestrogen preparation most commonly used in these studies contained conjugated equine oestrogens and a large proportion of oestrone sulphate (Premarin). This together with the "oestrone hypothesis" " namely, that unopposed exposure to oestrone of a target organ such as the endometrium might be causally related to cancer-led to condemnation of the use of oestrogen preparations containing oestrone sulphate for menopausal symptoms. ${ }^{9}$ It was also suggested ${ }^{9}$ that oestradiol and oestriol might be safer alternatives so far as the risk of endometrial carcinoma was concerned. That this might not be true for oestradiol, however, was suggested by Yen et $a l^{10}$ and Jacobs et $a l,{ }^{11}$ who showed that oral micronised oestradiol or oestradiol valerate given to postmenopausal women resulted in circulating concentrations of oestrone greater than those of oestradiol. Although concentrations of oestrone sulphate, a conjugated oestrogen quantitatively the most important circulating oestrogen in premenopausal women, ${ }^{12} 13$ were not measured, it seems likely that they also become greater when oestradiol is ingested, since oestradiol, oestrone, and oestrone sulphate are in equilibrium in the circulation. ${ }^{13} 14$

We tried to resolve the controversy by measuring concentrations of oestradiol, oestrone, and oestrone sulphate in postmenopausal women who were taking oral preparations of either oestrone sulphate (Harmogen; piperazine oestrone sulphate) or oestradiol (Progynova; oestradiol valerate). 


\section{Patients and methods}

We studied 17 postmenopausal women who were being given oral oestrogens for menopausal symptoms, mainly hot flushes and sweats. Ten of the women were taking oestradiol valerate $2 \mathrm{mg}$ daily, and seven were taking piperazine oestrone sulphate $1.5 \mathrm{mg}$ daily. All had been receiving oestrogens for at least six weeks but stopped treatment 48 hours before the study began. Peripheral venous blood samples were taken before and two, four, and six hours after a dose of oestradiol $2 \mathrm{mg}$ or oestrone sulphate $1.5 \mathrm{mg}$, patients being given the same oestrogens as they had been taking previously. The serum was separated by centrifugation and stored at $-20^{\circ} \mathrm{C}$ until assayed.

Serum concentrations of oestradiol-17 $\beta$, oestrone, and oestrone sulphate were measured in all samples by means of radioimmunoassay. To duplicate samples of $0.5 \mathrm{ml}$ serum, $1000 \mathrm{cpm}\left(6,7-{ }^{3} \mathrm{H}\right)$ oestrone sulphate was added to allow for manipulative losses, and the unconjugated oestrone was extracted from the serum with $5 \mathrm{ml}$ diethyl ether. An aliquot $(0.2 \mathrm{ml})$ of the aqueous residue was then taken, $0.3 \mathrm{ml}$ saturated sodium chloride solution added, and the conjugated oestrogen extracted with $2.5 \mathrm{ml}$ butanone. The dried butanone extract was taken up in $0.5 \mathrm{ml}$ solution of aryl sulphatase (type V, Sigma Chemical Co, Missouri; $0.2 \mathrm{mg}$ sulphatase $/ \mathrm{ml}$ sodium acetate, $\mathrm{pH}$ 5.0) and incubated at $37^{\circ} \mathrm{C}$ overnight to cleave the sulphate. The resultant unconjugated steroid was extracted with diethyl ether. The ether extract was dried and taken up in $0.5 \mathrm{ml}$ phosphate buffer, and $0.2 \mathrm{ml}$ was taken to assess procedural losses; an appropriate aliquo $(0.1$ or $0.05 \mathrm{ml})$ was then taken for radioimmunoassay of oestrone. For estimations of oestradiol- $17 \beta$ concentrations, $0.5 \mathrm{ml}$ serum in duplicate was extracted with diethyl ether and the dried extracts were taken up in phosphate buffer.

Standard radioimmunoassay techniques were used to measure oestradiol-17 $\beta$ and oestrone, antisera of high specificity being used The assay for oestradiol was essentially the same as described ${ }^{15}$ and was carried out with an antiserum to oestradiol-6-carboxymethyloxime conjugated to bovine serum albumin. There was no crossreaction of oestrone with oestradiol antiserum or of oestradiol with oestrone antiserum. The lower limit of sensitivity of the oestrone assay was $37 \mathrm{fmol}(10 \mathrm{pg})$, and of the oestradiol assay $18 \mathrm{fmol}(5 \mathrm{pg})$. For oestrone sulphate the mean recovery of the tritiated steroid ( \pm SE of mean) was $57 \cdot 9 \pm 1 \cdot 1 \%(n=147)$; the interassay coefficient of variation was $10 \%(n=10)$. Allowance was made for the difference in molecular weight between oestrone and its sulphate by multiplying by 1.4 the amount of oestrone cleaved from the sulphate. Differences between means were tested for significance with the Mann-Whitney rank sum test.

\section{Results}

Mean serum concentrations ( $\pm S E$ of mean) of oestradiol, oestrone, and oestrone sulphate for all patients before and up to six hours after taking oestradiol valerate or piperazine oestrone sulphate are compared in figs 1 and 2 . There was no significant difference at any time in the three oestrogen concentrations between the patients who had taken oestradiol and those who had taken oestrone sulphate. The concentrations of oestradiol in both groups remained at 294-367 pmol/1 $(80-100 \mathrm{pg} / \mathrm{ml})$ for the six hours after taking the tablets, whereas both oestrone and oestrone sulphate concentrations showed a fourfold to eightfold rise over the pretreatment values.

Mean baseline concentrations of oestradiol were higher than those of oestrone but after treatment concentrations of oestrone rose to about twice those of oestradiol. Oestrone sulphate concentrations before and after treatment were much greater than those of either oestrone or oestradiol, reaching a peak of some $23 \mathrm{nmol} / 1(9 \mathrm{ng} / \mathrm{ml})$ at four hours-about 30 times the concentration of oestrone in the same serum samples.

\section{Discussion}

These findings show that whether postmenopausal women take oestradiol valerate or piperazine oestrone sulphate virtually identical concentrations of oestradiol, oestrone, and oestrone sulphate will appear in the circulation, although oestrone sulphate is quantitatively the most important oestrogen. The rapid metabolism of oestradiol valerate to oestrone and oestrone sulphate, which may occur in the gastrointestinal tract, ${ }^{16} 17$ lends no support to the suggestion ${ }^{9}$ that there is less risk of endometrial carcinoma in taking oestradiol than in taking oestrone sulphate. Our results suggest that the two oral oestrogen preparations, oestradiol valerate and piperazine oestrone sulphate,

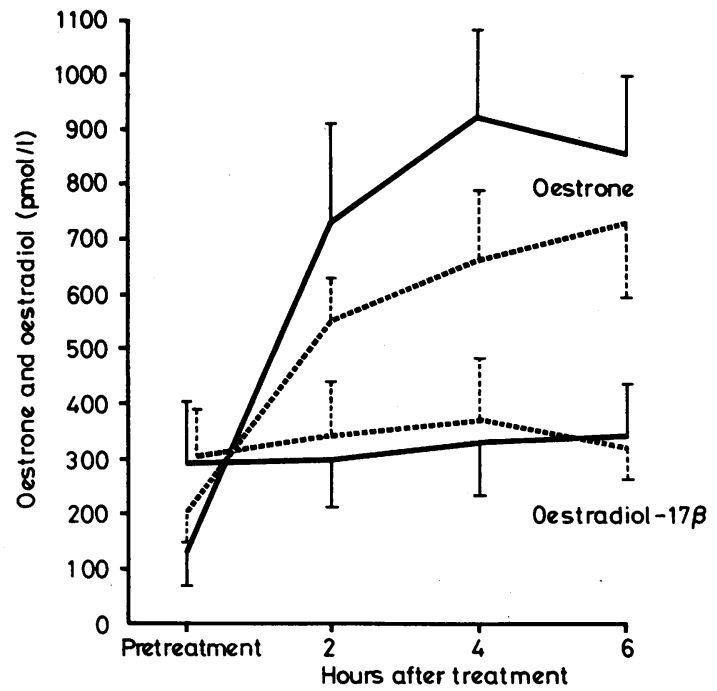

FIG 1-Mean serum concentrations ( $\mathrm{SE}$ of mean) of oestrone and oestradiol-17 $\beta$ before and at two-hour intervals after oral piperazine oestrone sulphate $1.5 \mathrm{mg}(--.-)$ and oestradiol valerate $2 \mathrm{mg}(\longrightarrow)$ in postmenopausal women.

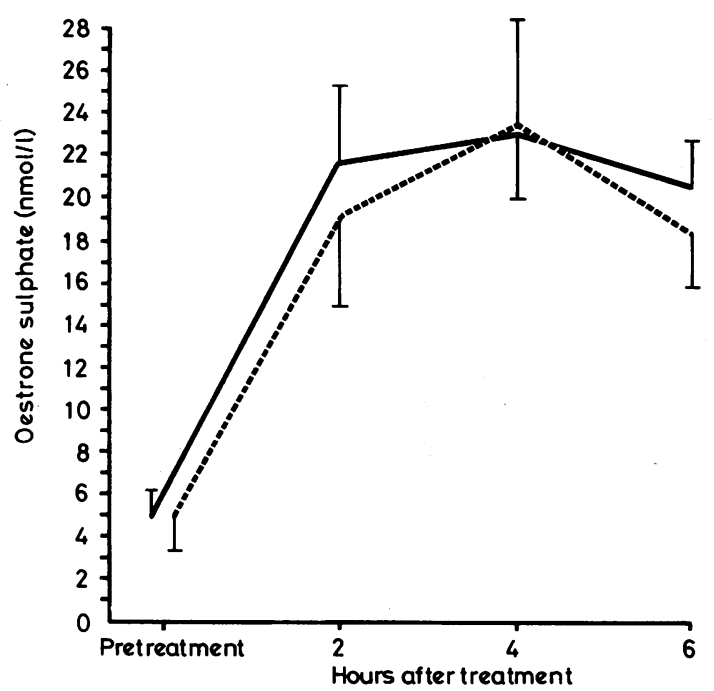

FIG 2-Mean serum concentrations ( \pm SE of mean) of oestrone sulphate before and at two-hour intervals after oral piperazine oestrone sulphate $1.5 \mathrm{mg}\left(-_{--}\right)$and oestradiol valerate $2 \mathrm{mg}(-)$ in postmenopausal women.

may, in fact, be identical in so far as they affect the serum concentrations attained by three major oestrogens.

There was little change in the oestradiol concentrations after treatment, and the final range of concentrations of 294-367 $\mathrm{pmol} / \mathrm{l}(80-100 \mathrm{pg} / \mathrm{ml})$ was within that found early in the menstrual cycle in premenopausal women. The mean baseline concentration was well above postmenopausal values, but there was wide variation among patients; several had pretreatment concentrations below $73 \mathrm{pmol} / \mathrm{l}(20 \mathrm{pg} / \mathrm{ml}) 48$ hours after taking their last tablet.

The mean concentrations of oestrone after treatment were similar to or slightly higher than the highest concentrations found during the menstrual cycle, which occur at mid-cycle, before ovulation. ${ }^{18}$ Oestrone sulphate concentrations during treatment reached three to four times the peak values found at mid-cycle. ${ }^{12}$

The term "replacement therapy" for oestrogen treatment in postmenopausal women is thus a misnomer, as the only oestrogen apparently replaced is oestradiol, which substantiates the findings of others. ${ }^{11}$ The high concentrations of oestrone and particularly of oestrone sulphate after treatment represent a 
pharmacological effect if comparison is made with physiological concentrations of these oestrogens in the menstrual cycle. On the other hand, during pregnancy peripheral concentrations of oestrone and oestrone sulphate become much greater $^{19}$ than those measured in these postmenopausal women receiving oestrogens. Since the risk of endometrial carcinoma is greater in nulliparous than in multiparous women one might argue that raising oestrogen concentrations above those found during the menstrual cycle might even be protective against endometrial cancer; this is not borne out, however, by epidemiological evidence, ${ }^{1}{ }^{2}{ }^{2}$ ? and controversy continues.

The retrospective studies from the United States suggesting a link between hormone treatment at the menopause and endometrial carcinoma were concerned almost exclusively with unopposed oestrogen treatment, and one may speculate from our results that high concentrations of oestrone or oestrone sulphate rather than oestradiol are responsible. It seems unlikely to be harmful to maintain after the menopause oestradiol concentrations similar to those found during menstruation. Alternatively, since the major oestrogen used in the studies from the United States was a preparation of equine origin containing 20 different steroids, ${ }^{20}$ oestrone sulphate of human origin cannot necessarily be incriminated. A recent paper suggests that the excess risk of endometrial carcinoma applies to systemic oestrogens of various kinds, and not only to conjugated equine oestrogens. ${ }^{7}$ Good prospective epidemiological studies are needed to confirm or refute the American evidence but our results suggest that ingesting oestrone sulphate is unlikely to be associated with any greater risks of endometrial carcinoma than ingesting oestradiol.

We thank all patients who co-operated in this study, Abbott Laboratories for financial support, and Miss P Shepheard for typing the manuscript. The oestradiol antibody was the generous gift of Dr W Collins, King's College Hospital Medical School, London. The oestrone antiserum oestrone-6-carboxymethyloxime was obtained from Steranti Research Ltd, St Albans.

\section{References}

1 Smith, D C, et al, New England fournal of Medicine, 1975, 293, 1164.

2 Zeil, H K, and Finkle, W D, New England fournal of Medicine, 1975, 293, 1167.

${ }^{3}$ Cooke, I D, British Medical fournal, 1976, 1, 1209.

4 Studd, J, British Medical fournal, 1976, 1, 1144.

5 Lancet, 1977, 1, 577.

- Mack, T M, et al, New England fournal of Medicine, 1976, 294, 1262.

' Gray, L A, Christopherson, W M, and Hoover, R N, Obstetrics and Gynecology, 1977, 49, 385.

8 Siiteri, P K, Schwartz, B E, and MacDonald, P C, Gynecologic Oncology, $1974,2,228$.

- British Medical fournal, 1976, 1, 791.

10 Yen, S S C, et al, Fournal of Clinical Endocrinology and Metabolism, 1975, $40,518$.

11 Jacobs, H S, et al, Current Medical Research and Opinion, 1977, 4, suppl No 3, p 58.

12 Hawkins, R A, and Oakey, R W, Fournal of Endocrinology, 1974, 60, 3.

13 Reeder, H J, Loriaux, L, and Lipsett, M B, fournal of Clinical Investigation, 1972, 51, 1020.

14 Longcope, C, fournal of Clinical Endocrinology and Metabolism, 1972, 34, 113.

15 Turnbull, A C, et al, Lancet, 1974, 1, 101.

${ }_{16}$ Ryan, K J, and Engel, L L, Endocrinology, 1953, 52, 287.

17 Diczfalusy, E, et al, Acta Endocrinologica, 1962, 40, 537.

18 Emment, Y, Collins, W P, and Sommerville, I F, Acta Endocrinologica, 1972, 69, 567.

19 Turnbull, A C, et al, in The Fetus and Birth, ed J Knight and M O'Connor, p 427. Amsterdam, Elsevier, 1977.

${ }^{20}$ Lauritzen, C, Frontiers in Hormone Research, 1975, 3, 30.

(Accepted 27 October 1977)

\title{
Serum tolbutamide and chlorpropamide concentrations in patients with diabetes mellitus
}

\author{
A MELANDER, G SARTOR, E WÅHLIN, B SCHERSTÉN, P-O BITZÉN
}

British Medical fournal, 1978, 1, 142-144

\section{Summary and conclusions}

A selective and sensitive gas chromatographic technique was used to measure the steady-state serum concentrations of tolbutamide and chlorpropamide in 97 patients with maturity-onset diabetes mellitus who had been taking these drugs (37 tolbutamide, 60 chlorpropamide) for at least a year. No other antidiabetic agents had been given. The serum tolbutamide concentrations varied widely between the patients (from close to zero to 370 $\mu \mathrm{mol} / 1(100 \mu \mathrm{g} / \mathrm{ml}))$, yet the variation in dosage was only sixfold (0.5-3.9 g daily). The serum chlorpropamide concentrations varied even more widely (from close to zero to $882 \mu \mathrm{mol} / 1(244 \mu \mathrm{g} / \mathrm{ml}))$, though the dosage variation was fourfold (125-500 $\mathrm{mg}$ daily). There was no

Lund University Hospital, EA-blocket 5tr, S-221 85 Lund, Sweden A MELANDER, MD, acting professor of clinical pharmacology G SARTOR, MD, resident, department of internal medicine E WÁHLIN, BSC, chemist, department of clinical pharmacology B SCHERSTÉN, MD, associate professor of internal medicine

Department of Community Care Sciences, Primary Care Centre, Dalby, Sweden

P-O BITZÉN, MD, district doctor systematic relation between dosage and serum concentrations of the drugs.

Only $2(5.4 \%)$ of the tolbutamide-treated patients and $10(16.7 \%)$ of the chlorpropamide-treated patients had normal fasting blood glucose concentrations (below $5.5 \mathrm{mmol} / 1$ (99 $\mathrm{mg} / 100 \mathrm{ml}))$, and fewer than half had values below $8.0 \mathrm{mmol} / 1(144 \mathrm{mg} / 100 \mathrm{ml})$. In most cases, therefore, the treatment was insufficient.

There was no significant difference in mean fasting blood glucose concentrations between the two treatment groups. The mean steady-state concentration of chlorpropamide, however, was significantly higher than that of tolbutamide. Thus, contrary to common belief, the intrinsic activity of chlorpropamide is apparently not greater than that of tolbutamide. The alleged greater potency of chlorpropamide seems to be related wholly to kinetic differences, such as the less extensive metabolic degradation and slower elimination of the drug.

We conclude that treatment with sulphonylureas in conventional dosage is far from optimal and that monitoring the concentrations of these drugs in the blood may help to improve their efficacy.

\section{Introduction}

The choice of drug is a major prerequisite for successful treatment, but so also is adequate dosage. Much if not most of the 